\title{
Article
}

\section{The Theory of the Offender's Forfeited Right}

Rosebury, Brian John

Available at http://clok.uclan.ac.uk/12870/

Rosebury, Brian John ORCID: 0000-0002-6154-2685 (2015) The Theory of the Offender's Forfeited Right. Criminal Justice Ethics, 34 (3). pp. 259-283. ISSN 0731-129X

It is advisable to refer to the publisher's version if you intend to cite from the work. http://dx.doi.org/10.1080/0731129X.2015.1106793

For more information about UCLan's research in this area go to http://www.uclan.ac.uk/researchgroups/ and search for <name of research Group>.

For information about Research generally at UCLan please go to http://www.uclan.ac.uk/research/

All outputs in CLoK are protected by Intellectual Property Rights law, including Copyright law. Copyright, IPR and Moral Rights for the works on this site are retained by the individual authors and/or other copyright owners. Terms and conditions for use of this material are defined in the policies page.

\section{CLoK}

Central Lancashire online Knowledge www.clok.uclan.ac.uk

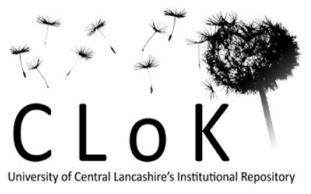




\section{The Theory of the Offender's Forfeited Right}

Brian Rosebury

\section{Abstract}

In justifying punishment we sometimes appeal to the idea that the punished offender has, by his criminal action against others, forfeited his moral right (and therefore his legal right) against hard treatment by the state. The imposition of suffering, or deprivation of liberty, loses its prima facie morally objectionable character, and becomes morally permissible.

Philosophers interrogating the forfeited right theory generally focus on whether the forfeiting of the right constitutes a necessary or a sufficient condition for punishment to be permissible; rarely do they ask whether the idea of a right that can be forfeited is itself morally illuminating. The paper examines and criticizes various versions of this theory. It concludes that the forfeited right arguments add little other than rhetorical dignity to the existing repertoire of justifications for punishment. They can be most usefully understood as communicating the thought that the offender cannot reasonably complain about the violation of rights he himself has violated. But the incapacitation of the offender's reasonable complaint does not entail that we are justified in punishing him.

Keywords: criminal justice, punishment, retributivism, forfeiture, rights 


\section{I.}

In justifying punishment we sometimes appeal to the idea that the punished offender has, by his criminal action against others, forfeited his moral right (and therefore his legal right) against deprivation of liberty, or other hard treatment. The suffering or hardship that punishment involves would normally stand as a moral barrier against its imposition on a fellow citizen. But the offender's affliction of others is sufficient to justify his own affliction by the state. ${ }^{1}$ Granting various other conditions, such as a fair trial and the presence of legitimate authority to punish, such affliction loses its prima facie morally objectionable character and becomes morally permissible. Versions of this theory can be found in contemporary philosophy, in classical philosophers such as Locke and Fichte, and -more informally, but no less pungentlyin the utterances of judges, politicians, and ordinary citizens. In this paper, I attempt an exposition and critique of the theory in its many versions.

If the theory is to get off the ground, it must go beyond the tautology that a conditional legal right is forfeited if the condition for its possession is not met. Rather, it must give a distinctively moral explanation for the forfeiting of a legal right. Here is the theory in its most rudimentary form:

(1) X has afflicted Y (for no good and sufficient compensating purpose). ${ }^{2}$

(2) Afflicting people (for no good and sufficient compensating purpose) is morally wrong.

(3) Therefore $(1+2) \mathrm{X}$ has done something morally wrong. 
(4) Therefore, $X$ (in virtue of 1-3) no longer has a moral defense against being afflicted in a similar way to, or to a similar extent as, his own affliction of $Y$. In the context of criminal justice, $\mathrm{X}$ may be said to forfeit his right against comparable affliction imposed as punishment. (In cases of homicide, it is sometimes said that the person who kills a fellow-citizen has "forfeited his own right to life.")

Rights forfeiture as a legal and political event thus corresponds on this rudimentary view to an intuitive deontic judgement, appealing to a kind of symmetry: $\mathrm{X}$ who has wrongfully afflicted Y may in consequence be rightfully afflicted by the state.

It is tempting to dismiss this "symmetrical" thesis as a disguised expression of retributive anger, but that would be unfair, or at least premature. Those who advocate the thesis do not think they are (merely) expressing anger: they think they are providing a persuasive, morally serious and compelling reason for action. ${ }^{3}$ We should consider whether their argument can be developed effectively. A more plausible excuse for dismissing the thesis is that it is simply a fancy re-wording of the claim that the offender deserves punishment for his crime. But again, this criticism may be unfair. There may be some distinctive justificatory force in the forfeited right idea that no other theory can provide.

We should begin by noting that there are two ways of construing the theory. Sometimes, it seems to be offering a substantive justification for punishment. On this view, X's forfeiting of his legally protected moral right provides the permissive justification for his being punished. I will call this claim that the forfeiting of a right 
is a substantive justification for punishment the aggressive use of the forfeited right theory.

I have heard it said that no competent theorist of punishment really believes in this aggressive use, so that to attack it in a philosophical article would be a waste of effort. Instead, it is suggested, we justify punishment by reference to other considerations (deterrence, retribution, incapacitation, etc.). Having justified punishment for these other reasons, we now have to explain what has happened to certain moral and legal rights the punished offender must originally have had like the rest of us; for example, the right not to be seized and imprisoned. The forfeited right theory is an attempt to explain, without weakening the force of these rights, why they have not been violated by the act of punishment. I call this the defensive use of the forfeited right theory.

In section VI below, I will return to this defensive use. But first, we will look for whatever arguments can be advanced to support the aggressive construal of the theory and evaluate them. And, as we will eventually see, the "defensive" version is unsustainable without ultimately appealing to the special justificatory significance of the forfeiting of right.

\section{II.}

To begin to evaluate the theory, we need to return to (4), the conclusion that emerges from its rudimentary statement. Why might it seem plausible that, by afflicting X, Y should have forfeited a right not to suffer some affliction in turn? Indeed, what is meant by this claim? We can immediately distinguish two elements: (i) a general, 
underlying claim, that my afflicting another person makes it permissible for the state to afflict me, and (ii) the specific version of this claim that invokes the concept of a forfeited right.

It would be possible to smooth over this distinction by returning to claim (1) and rephrasing it as follows:

$\left(1^{*}\right) \mathrm{X}$ has violated a right possessed by $\mathrm{Y}$.

But the invocation of rights need not come in at this foundational level. The fact that $\mathrm{X}$ has hurt or harmed or incommoded someone for no good reason may be thought in itself sufficient to remove the standing inhibition recognized by morally sensitive people against the hurting or harming or incommoding of $\mathrm{X}$. The reference to the crime victim's violated right serves to translate into the moral and legal discourse of rights the intuitively perceived symmetry between the affliction $\mathrm{X}$ has wrongly caused and the affliction he must now justly incur. But the moral transaction can be explicated just at the level of the raw phenomenology: this unpleasant experience caused by $\mathrm{X}$ to $\mathrm{Y}$ gives us a reason to impose that unpleasant experience on $\mathrm{X}$.

Much modern discussion of the forfeited right theory, for example by Warren Quinn, Christopher Morris, Christopher Wellman and David Alm, ${ }^{4}$ ignores or quickly marginalizes this more primitive consideration: it treats the existence of certain rights as given, and sets out to consider whether an offender may forfeit his own right or rights in light of his violation of someone else's rights. The discussion comes to be framed entirely within an apparatus of rights, and moral conceptions outside that apparatus are discounted. Alm makes this explicit by identifying a "moral" 
justification of a practice with a justification which shows that it infringes no rights: a justification in terms of benign consequences or retributive appropriateness being merely a "rational" justification. ${ }^{5}$ But the moral question could be formulated as follows: why does the affliction of $\mathrm{Y}$ by $\mathrm{X}$ make permissible the affliction of $\mathrm{X}$ by ourselves, when our afflicting of X would usually be regarded as wrong? Quinn finds "deeply disturbing" the idea that "punished persons have no rights that stand against their punishment because ... punishing them is so often useful in helping to deter others from committing crimes. ${ }^{6}$ [Italics added.] But an equally disturbing thought is that the moral principle that

(2) afflicting people (for no good and sufficient compensating purpose) is wrong

has no application to convicted offenders.

For "pure" retributivism, which treats the ill desert of the offender, incurred by his wrongdoing, as both necessary and sufficient reason for punishment, ${ }^{7}$ the forfeited right theory offers a formulation that fixes retribution within the discourse of rights. ${ }^{8}$ The retributive flavor of the theory comes from the fact that it seems to redirect to the offender the responsibility for the hard treatment or deprivation he will suffer as punishment. His sabotaging of his own protective right is at least part of what makes our afflicting him permissible. This claim goes beyond the banal point that a person who commits an offense makes it likely that he will suffer punishment. That would be true even if the punishment was morally entirely unjustified, as in the case of a heroic dissenter punished under an unjust law. Rather, the idea is that the 
offender's wrongly afflicting another or others provides a sufficient moral justification for our afflicting him. The natural suspicion that our afflicting him might be a further wrong is allayed by this point about the forfeiting of his right. We do not need to look elsewhere for a sufficient compensating purpose, such as deterrence.

A consequentialist theory might also deploy the idea of the offender's forfeited right, but its "symmetrical" significance would be different. A consequentialist who accepted the utility of a stable system of positive rights enjoying high levels of confidence and compliance could support a punitive model whereby those who, by their own violations, had disrespected the system of rights were punished with the temporary loss of some right of their own. Such punishment, the consequentialist might argue, would deter future violations of right and enhance confidence in the system. But the symmetry would lie purely at the institutional level. Since the consequentialist is not concerned to justify retribution for desert, the claim that the offender had forfeited a right would be at most a "defensive" stratagem (see section VI), or another way of saying that a legal penalty attaches to the offense, the "right forfeited" being the negative legal right not to incur a penalty when one has not done the action to which the penalty is attached. The penalty could be expressed as reflecting the loss of a right, but the moral reason for so expressing it would be to give effect to, and maintain public confidence in, the system of rights, not to present the offender as the agent of his own punishment. To say that the offender had forfeited a right would be equivalent to saying that he had committed an offense, formulated in terms of the system of rights, carrying a penalty also formulated in such terms. Rights forfeiture, then, would therefore be merely part of the modus operandi of a system justified by its propensity to bring about the best consequences. 
In a retributivist conception, however, the forfeiting of a right may be given distinct and independent normative weight. It reflects, on the aggressive construal of the theory, the change in X's desert that occurs when X knowingly or recklessly violates some principle of conduct towards others that, if universally obeyed, would protect $\mathrm{X}$, in common with others, from intentionally caused harm. That $\mathrm{X}$ has violated that principle gives the state, subject to legal processes, moral permission to give $X$ the hard treatment he deserves.

The most stringent form of retributivism holds that the state has a moral obligation, ${ }^{9}$ not merely a moral permission, to achieve justice by imposing the punishment that the offender deserves. In the rest of the paper, I will assume that only permission to punish needs to be established, since this is the crucial step needed to counter the prima facie moral objection to afflicting another. The further step from permission to obligation would follow, if we held for independent reasons that the state had an obligation to treat every forfeiture of right as a case for punishment. This is indeed a tenable position (and the independent reasons might be supplied by the consequentialist's imperative to make fully effective the system of rights, or by the retributivist's imperative to achieve justice); but the forfeited right argument is more naturally understood permissively, that is as disabling the standing moral objection to intentionally afflicting a fellow human being.

\section{III.}

If we look at invocations of rights forfeiture in the courts, we see that often the statement that the offender has forfeited a right is simply a concealed tautology, a 
rephrasing of the actual position in law. When in 2007 Judge Edward Nicholas told Blaine Ross, "you have not only forfeited your right to live among us, but under the laws of the state of Florida, you have forfeited your right to live at all" (Sarasota Herald-Tribune November 17, 2007), his remark can be understood as stating no more than that by a proper application of the laws of Florida to his case, Ross had been condemned to death as a consequence of his criminal actions. To say that he has forfeited a right to live is just another way of saying that Florida authorizes the death penalty in cases such as his. Here, no normative argument is being offered. ${ }^{10}$

Sometimes, on the other hand, the positive assertion of law seems to be subordinate to a normative claim. The comments of Mr Justice Humphreys, sentencing John Amery to death for high treason in 1945, provide an example:

John Amery . . . I am satisfied that you knew what you did and that you did it intentionally and deliberately after you had received warning from more than one of your fellow countrymen that the course you were pursuing amounted to high treason. They called you a traitor and you heard them; but in spite of that you continued in that course. You now stand a self-confessed traitor to your King and country, and you have forfeited your right to live. (The Times, November 29, 1945.)

The conjunction in the final sentence glosses over an ambiguity. Despite the statement's air of self-evidence, it does not even appear to follow from the fact that Amery is a self-confessed traitor that he has forfeited his right to live. Humphreys' 
use of and rather than therefore may betray awareness that some logical connection has been elided. Perhaps Humphreys, like Nicholas, is just implicitly alluding to the fact that the relevant law permits or mandates the death penalty in such cases, and is not offering a moral justification. But the preceding sentences seem to be preparing the ground for such a justification. Humphreys emphasizes the fact that Amery intentionally acted in a way he knew would entail capital punishment if he were convicted: he seems, therefore, implicitly to be claiming that Amery was morally responsible for causing his own impending execution.

That claim, however, would be false, or at best only partially true. The state decided to execute Amery, and it could have acted otherwise. Some account must be given of the moral justification of this action if the claim is indeed a normative one. The assertion that Amery had voluntarily forfeited the right to remain alive (though this was surely not his deliberate intention) fills the place of this missing justification, while remaining unexplained itself.

We should note that the analogy of private self-defense will not support the claim that the criminal should be ascribed moral responsibility for his own affliction by the law. If A credibly threatens B's life, and B kills or incapacitates A in selfdefense, A can rightly be ascribed primary causal responsibility for the harm he suffers at B's hands, since by his own action he placed B in a position of having no seriously eligible option but to defend herself by force. ${ }^{11}$ That is what the justification of self-defense means: that one has no seriously eligible alternative option but to strike down one's assailant. But it does not follow that the criminal can be ascribed responsibility for his punishment in the same way: the state has a range of eligible options, all of which require moral justification. Moreover, even in the self-defense 
case, the primary causal responsibility of the assailant for the affliction he suffers is not necessarily moral responsibility: we are not less entitled to strike down the assailant who attacks us if he has been tricked into taking an aggression-inducing drug and so is morally innocent. Some further argument is needed to show that the moral character of the criminal's act creates a moral permission for us to afflict him.

The most uncompromising recent adherent of the rights forfeiture theory is Wellman, who remarks that

[r] egarding those who deny that violating the rights of others alters the moral status of the wrongdoers, we simply agree to disagree, and I must concede that my arguments will have no purchase with them. ${ }^{12}$ [Italics added.]

The sceptic about rights forfeiture, it is implied, is one who takes a strangely forgiving attitude to people's violations of other people's rights. But the sceptic may be denying, not that the violation of a citizen's rights justifies punishment of the violator, but that the justification lies in some supposed symmetrical relationship or equivalence between violated victim rights and "forfeited" offender rights.

Whether the violation of another's right "alters the moral status" of the violator depends on what you mean by "alter the moral status." To clarify this point, we can consider the example Wellman offers to illustrate his view:

Imagine that Victim and Bystander are eating their lunches, when suddenly, without provocation, Criminal punches Victim in the face and then runs off with Victim's briefcase. All that the rights forfeiture thesis alleges is that 
Criminal's moral status has changed in such a way that Victim (or perhaps the authorities) may now treat Criminal in a way that would have been impermissible before Criminal struck Victim and stole her briefcase. That is, before Criminal violated Victim's rights, Victim (or the authorities) could not permissibly do anything to Criminal that she could not also do to Bystander, but this is no longer the case. Finally, the rights forfeiture theorist claims that the reason Victim (or the authorities) may now treat Criminal in ways that she (or they) cannot treat Bystander is because, in acting the way she did, Criminal forfeited her rights against this treatment. ${ }^{13}$

Here, the rights forfeiture thesis is stated in three sentences. The first of these,
All that the rights forfeiture thesis alleges is that Criminal's moral status has changed in such a way that Victim (or perhaps the authorities) may now treat Criminal in a way that would have been impermissible before Criminal struck Victim and stole her briefcase,

sceptics can accept, provided that the clause to which italics are here added is either regarded as a mere redundancy, or deleted. We can agree that Victim may justifiably fight to recover his briefcase, and that the authorities may justifiably punish Criminal for the theft and the assault. This change to the set of morally acceptable actions towards Criminal, occurring in light of his actions, could, if one wished, be expressed by saying that Criminal "has an altered moral status," or has "forfeited a right." But these ways of describing the new situation create tautologies, if all we mean by 
saying that Criminal "has an altered moral status," or "has forfeited a right" is that it is now permissible for us to grapple with him or punish him. Many of our actions provide reasons for other people to do things to us which would not be permissible had we not performed them. For example, if I begin to earn income above a certain threshold, it may become permissible for the government to recover income tax from me; and this could be expressed by saying that I have "forfeited a right" I previously "possessed," not to have some of my income taken away. But this reformulation in terms of forfeited right adds nothing to the assertion that we may permissibly grapple or punish or tax, and in particular, it does not identify any new reason or criterion whereby the permissibility of grappling, punishing or taxing may be judged. For the claim in the first sentence to be illuminating, the statement that that Criminal has "forfeited a right" must provide an additional justifying reason.

The second and third sentences in Wellman's example add a hint of a reason.

[B]efore Criminal violated Victim's rights, Victim (or the authorities) could not permissibly do anything to Criminal that she could not also do to Bystander, but this is no longer the case. ... [T]he reason Victim (or the authorities) may now treat Criminal in ways that she (or they) cannot treat Bystander is because, in acting the way she did, Criminal forfeited her rights against this treatment.

The morally significant change, then, begins with the violation of Victim's rights, and concludes with the forfeiting of Criminal's rights against some (unspecified, but presumably punitive) treatment. The implication is that some symmetry or 
equivalence is involved between these two kinds of right. But this symmetry or equivalence needs to be explained. Wellman makes a further claim for its selfevidence by concluding from his example that "it seems obvious that rational/human beings qualify for rights that can be forfeited by bad behavior."14 The intuitive idea seems to be that, once we recognize that our moral and political values are to be expressed in the language of rights, it must be the case that our morally justified response to the violation of a right will take a form which is itself expressed in the language of rights; and what form could that be, other than the forfeiting by the violator of some right? If rights are the currency, all transactions must take the form of the exchange or transfer of rights.

But if we translate the claim out of the language of rights, we arrive at roughly the following formulation:

It seems obvious that we should not afflict people, except that we should (or at least may) afflict people when they afflict other people.

This view is defensible, but its truth is not self-evident.

\section{IV.}

If the forfeiting of a right is supposed to have a distinctive moral significance, we need to understand the moral basis on which we acquired the right in the first place. Versions of the rights forfeiture theory are therefore necessarily framed within some conception of the origin of the right that comes to be forfeited. 
$\mathbf{R 1}$ We possess the right only because it has been granted to us by society. If it has been granted on some condition, our failure to fulfill the condition makes us liable to forfeit it.

R2 We possess the right in virtue of our humanity, but we contract to transfer it to the care of society on entering the domain of law, and in this socially implemented form it is liable to be forfeited should we break the law.

$\mathbf{R 3}$ We possess the right in virtue of our humanity, whether or not we are members of a society, but can nevertheless forfeit it by actions whereby we cease to belong to humanity.

All three views have powerful exponents in the philosophical literature on rights and punishment. Though their precise formulation might be contested, and the distinctions among them are sometimes eroded in exposition and debate, they cover all possibilities, since a forfeitable right must be held either in virtue of being human, or as a consequence of participating in a society, and must either be transferable from the former condition to the latter, or be common to both. In this section, I will consider examples of all three conceptions.

In the case of $\mathbf{R} \mathbf{1}$, the moral question in justifying punishment is whether society's dealing with its members in this way is morally permissible. (Bear in mind, for all three conceptions, that we cannot simply say that it is permissible because it 
gives the offender his desert, since we are looking for a distinctive contribution from the forfeited right notion.)

R1 can be found as early as William Blackstone's Commentaries on the Laws of England, where the account of forfeiture of disposable or inheritable property rights in consequence of conviction for treason locates these rights purely within a social context.

The natural justice of forfeiture or confiscation of property, for treason, is founded in this consideration: that he who hath thus violated the fundamental principles of government, and broken his part of the original contract between king and people, hath abandoned his connexions with society; and hath no longer any right to those advantages, which before belonged to him purely as a member of the community: among which social advantages the right of transferring or transmitting property to others is one of the chief. ${ }^{15}$

This model of forfeitable "social advantages" possessed purely by reason of one's membership in the community can be extended beyond property to a wider set of rights that might be thought to be abrogated by punishment. A modern exponent of a fairly ambitious version of $\mathbf{R} \mathbf{1}$ is A. H. Goldman, who presents it as follows.

When one comes of age to establish relations with others on a moral basis, he acquires his full set of moral rights as well. Here full citizenship in a moral community, with all the protections that affords, is seen not as automatic or as a birthright, but as a privilege for which one must qualify... . [A]t least for 
adult persons, packages of rights and duties are reciprocal. One is not granted the full set of rights without accepting the full set of duties. The latter is both necessary and sufficient for the former.

According to this model, then, when a person violates rights of others he loses his standing in the moral community. .. . After proof of guilt, the criminal's package reverts temporarily to trusteeship by the community. ${ }^{16}$

On this view, the moral foundation of punishment lies in the presumed goodness of a moral community that regulates interpersonal relations in such a way that, if there is universal compliance, each respects the autonomy and integrity of all others. In Kantian terms, all are treated by all as ends in themselves. The community as a whole, acting through the criminal law, takes responsibility for correcting divergences from this ideal. But though this is in some ways an attractive vision, it fails to explain the afflicting character of punishment. If, in consequence of my failure to discharge the duty to respect another's right, I am punished by the temporary withdrawal of $m y$ rights, what does it reveal about the nature of those rights that in consequence of their withdrawal I may now be afflicted? If the form of punishment is imprisonment, for example, am I to understand that I qualified on coming of age for a conditional right not to be locked up, which I have now forfeited? On this model, the presumed initial situation, prior to the conferment of the now-forfeited right, is one in which the moral community is a sovereign armed with the power of affliction, which stays its hand in respect of individuals on condition of their compliance.

This conception cannot be easily refuted without moving into a more general area of political philosophy, but we can reasonably ask why a community that takes 
all its members as ends in themselves should think that the forfeiting of a conferred right by one of its members is, or at least may be, a sufficient reason to activate the power of affliction. Are adult human beings ends in themselves only in so far as they are compliant members of the society, ceasing to be so if they cease to be compliant? Morris offers a modified version of $\mathbf{R} \mathbf{1}$ that screens it from this objection, by distinguishing the "full moral standing" that makes us the objects of considerations of justice and benevolence from the "partial moral standing" that leaves us as merely the objects of considerations of benevolence. Only by entering into the "mutually beneficial convention" of justice do we gain full moral standing, which "presupposes the willingness to comply with the requirements of justice." ${ }^{17}$ Morris's view persuasively invokes a principle of fairness: that only those who fully participate in a co-operative enterprise are entitled to lay claim to its distinctive benefits. The disqualification from claiming the benefits of justice, as distinct from those of benevolence, could properly be expressed as the forfeiture of a legal right. But this position leaves us with the moral question of how to reconcile the hard treatment or deprivation involved in punishment with the residual human duty of benevolence. Goldman's theory emphasizes the benign objectives underlying the temporary trusteeship of the state over the punished person's rights, including pre-eminently the restoration of the offender to good reciprocal relations with others. We could, however, accept these objectives as desirable in themselves, as providing a more than compensating good purpose to set against the affliction involved in the punishment of the individual, and could then reasonably ask what additional justifying work is done by the notion of a forfeited right. It would be enough to say that punishment was 
justified by these benign objectives of a criminal law, which, if it is to be itself justifiable, requires among other things the consistent application of penalties.

According to $\mathbf{R 2}$, the forfeiting of a right can be understood as the outcome of a breach of contract. In the state of nature, according to the influential Hobbesian version of the theory, our original "natural right" is no more than a synonym for such power of self-defense and self-assertion as we may possess. By entering into society, we seek the benefits of a contract that gives us an enhanced (because sociallysupported) right against affliction by others, on condition that we transfer our original right to society. ${ }^{18}$ Just as a contractor who fails to carry out an agreed service forfeits the right to payment for that service, so (it might be claimed) a citizen who breaks the law thereby forfeits the right against affliction.

For this explanation to work, we would again need to know why the state of affairs prior to the contract of citizenship is supposed to be one that would give us reason to pay the price of compliance with the law - thus renouncing at least some of our own natural freedom to act without constraint in our own interest - and to submit to the risk of punishment. The answer is that in the pre-contractual situation, we will have no reason to suppose that relations between human beings will not be characterized by mutual aggression. The contract of citizenship creates for others a moral obligation, enforced by the law through the system of positive rights, to stay their hand against us, as long as we stay our hand against them. It is essential to the enhancement of our right that we can trust one another's compliance, for if we cannot, we all begin to have reason to reassert our powers of personal self-defense. ${ }^{19}$ Since violation of the contract by any party restores the unhappy state of potential conflict, we must be deterred from violation by the knowledge that we would as a 
result forfeit some protection of the law. We have a common interest in the preservation of the system of rights, and can plausibly contract for the possibility of our punishment as the price for assuring this common interest in which we participate.

This, however, is essentially the deterrent strategy mentioned in section II, in which a well-ordered system of rights is part of the modus operandi of a consequentialist project, and within which rights forfeiture has no independent normative significance: if a different modus operandi without rights forfeiture could produce even better results, the contracting parties would have reason to prefer it. What a retributive theory would need is a demonstration that we have reason to contract for the possibility of our own rights forfeiture on deontological grounds, irrespective of any common interest in which we might participate. If that could be achieved, the contractor could be held to be willing, and so morally legitimizing, the existence of a system of rights that would necessitate his own punishment on grounds of his ill desert alone.

It is difficult to see how this demonstration could be achieved without ignoring the instrumental rationality that motivates a contract, even a tacit one. To take the most drastic case, Cesare Beccaria is surely right to object that no citizen can be supposed to have transferred by tacit contract the right to order his own death. ${ }^{20}$ The whole point of a valid contract is that one knows in advance everything to which it commits one, including the worst-case outcome. Conceivably, an actual person who was not unduly risk-averse might enter into a contract entailing the possibility of his own death. But it is not plausible to suppose that this should be taken to be the content of the tacit contract by all citizens, given the much greater eligibility of a 
contract that would allow only punishments that spare the individual citizen's life. And this argument can then be pressed further to apply to all purely retributive punishments. The contracting parties have a rational motive for approving an effective criminal justice system, namely that they believe that, on the balance of probabilities, it will maximize their own chances of safety. But it is not clear what motive they could have for approving a system that would potentially punish them, or others, irrespective of any benefit to citizens in general in which they or their loved ones might participate. On almost any version of $\mathbf{R} 2$, then, the idea that a natural right is traded off for social protection gives the theory an instrumental character. Both from the point of view of the individual and from the point of view of the community, the point of the trade-off is to maximize safety in a dangerous world.

In one possible construal of $\mathbf{R 2}$, it might be thought morally permissible to afflict someone without reference to any compensating good purpose. This construal depends on the idea that, in consequence of his violation of right, the offender entirely forfeits membership of the moral community, so that the need for moral justification does not even arise. On Fichte's uncompromisingly holistic view of forfeiture, a citizen who breaks any law forfeits all his legal and moral rights, and anything may be done to him by others.

If a person violates any part of the civil contract ... then, strictly speaking, he loses all his rights as a citizen and as a human being, and becomes an outlaw with no rights at all. ${ }^{21}$ [Italics added.] 
The disproportion between the single offense and the complete loss of protection that results reflects the idea that any violation of the reciprocity of the social contract creates a state of war between ourselves and the violator: we are immediately free to act as ruthlessly as we wish to gain our ends at his expense (knowing that he may do likewise if he can). Given the extremity of this risk entailed by the violation of the contract, each of us, Fichte thinks, would have reason to agree in advance to a device that would enable us to retain the protection of law. This device is the "contract of expiation," whereby we undergo some appropriate punishment to secure readmission to the moral community rather than exile from it.

Fichte's view is thus at once an extreme form and a kind of inversion of the rights forfeiture theory. In consequence of his crime, the offender forfeits all rights, including his protection by us from the violence of others (a right that, at least in theory, convicted criminals in most contemporary societies enjoy). Yet the specific afflictions that are likely to follow his outlawing can hardly be called punishments, since when suffering them he will no longer be subject to the law: we will, indeed, have no standing to deal with him at all, other than as a potential antagonist in war. Instead, Fichte conceptualizes lawful punishment as a method whereby community protection may after all be retained. Punishment is not justified by the forfeiting of right, but is a precondition for the recovery of right. This may seem in practice to be much the same thing, but the difference is that the offender has the option of leaving the society altogether. Fichte thus avoids an awkward tension that seems to be latent within a contract-based rights forfeiture theory of punishment: the fact that it forces the offender to remain within the society and undergo punishment, yet cancels one or more of the rights that binds him to it. 
The third conception, $\mathbf{R 3}$, is that the right forfeited is possessed by us in virtue of our humanity, whether or not we are members of a society, and is forfeited by our ceasing to belong to humanity. We find it most effectively set out by Locke, in passages such as the following.

Man not having such an Arbitrary Power over his own Life, cannot give another Man such a Power over it; but it is the effect only of Forfeiture, which the Aggressor makes of his own Life, when he puts himself in the state of War with another. For having quitted Reason, which God hath given to be the Rule betwixt Man and Man, and the common bond whereby humane kind is united into one fellowship and society ... he renders himself liable to be destroied by the injur'd person and the rest of mankind, that will joyn with him in the execution of Justice, as any other wild beast, or noxious brute with whom mankind can have neither Society nor Security. ${ }^{22}$

It is not, according to Locke's analysis, the breach of the social contract that causes "Forfeiture." For Locke, our moral obligations are much the same whether we are in the state of "Nature" or of "Compact"; in the pre-contractual situation, we are subject "to the Law of Nature, i.e. to the Will of God," 23 and the positive law of a wellordered Commonwealth closely models the Law of Nature, or should do so. It does not matter whether natural law is violated through the crime of a felon, an act of military aggression against another community, or the violent interferences of a tyrannical government: these are all equally cases in which human beings "quit Reason," enter into a state of war with others, become like beasts, and so forfeit their 
lives. (The key difference in this respect between the pre-contractual situation and political society lies, according to Locke, in the assignment of the right to punish: prior to the contract, in the State of Nature, every person has the right to punish a wrongdoer, whereas by entering into society we transfer this right to the Legislative and its agents.)

This lurid comparison of the offender to a "beast, or noxious brute," which is repeated elsewhere in the Second Treatise in conjunction with the idea of forfeiture, ${ }^{24}$ is more than a colorful metaphor. It may be interpreted in two ways. It may express a consideration of prudence, a recognition that we have no option but to secure our own lives by destroying a potentially mortal enemy, such as a lion who springs on us in our cave. This consideration is not a retributive one: whether the enemy who threatens us deserves to be afflicted is irrelevant to the objective of securing our own safety. Or Locke's formulation may be read as an attempt to take account of the idea that we have certain rights just in virtue of being human, ${ }^{25}$ including the right to life. These, then, are the rights that we must "forfeit" if we are to be justifiably killed or afflicted; and if they are rights associated with being human, it is a rhetorical necessity to say that we forfeit them in consequence of ceasing to be human, that is, by becoming beasts.

So Locke might provide the following answer to the question why we are morally permitted to afflict the offender who has forfeited his right: we are so permitted because the Law of Nature, or (which is the same thing) the Will of God, mandates punishment for offenses, whether or not the offender and the punisher are members of political society. We then need to know why the Law of Nature requires that punishment be imposed. Locke reminds us that "the Law of Nature ... willeth 
the Peace and Preservation of all Mankind." ${ }^{26}$ A theory of natural law ultimately predicated on the love of God for human kind cannot generate reasons for killing or afflicting people that are not expressive of some generally benevolent purpose; hence, again, the rhetorical necessity to exclude the offender entirely from the category of human kind. The generally benevolent purpose would be to help to preserve all those who remain within that category. Our duty to punish offenders then arises from our duty to the preservation of humanity.

Locke goes on to write, in a more retributive vein, of a man's "having, by his fault, forfeited his own Life, by some Act that deserves Death."27 Locke's remark occurs in a discussion of the legitimacy of slavery, which he equates with "the state of War continued, between a lawful Conqueror, and a Captive." 28 One who has been lawfully conquered -the qualification is crucial- must have violated the Law of Nature, typically by an act of aggression, and so may be treated as a noxious brute: to be enslaved is, then, a preferable outcome to the death that could otherwise justly be inflicted. ${ }^{29}$

This passage shows that Locke associates the forfeiting of the right to life with the ill desert incurred by violating the Law of Nature. If violating God's Law does not incur ill desert, what could? We have at last reached an argument, unassailable in its own terms, that explains the symmetry whereby an immoral act by the offender causes him to forfeit a moral right against affliction by others. Both elements of the symmetry are inherent in the Law of Nature, which is the ground of human morality. To violate the Law is ipso facto to be one whom it is permitted to afflict.

But this claim provides little help to the secular construal of rights forfeiture. Either God prescribes a deserved punishment for violations of the Law of Nature 
because that Law, serving as it does the peace and preservation of mankind, is right, independently of his own will, or he prescribes it for violating a Law that is right simply in virtue of his having willed it. ${ }^{30}$ If the latter, we cannot follow Locke unless we are believers. If the former, a derived instrumental justification of punishment is the natural secular inference: it is right to punish breaches of a Law that serves the peace and preservation of mankind, because to do so is likely to be conducive to those ends. It would indeed be possible to add, or substitute, a purely retributive rationale to claim that we should punish the Law-violator for some reason other than to serve the benign purposes of the Law, reducing these to a welcome side-effect - but Locke does not advance one, if we set aside the appeal to God's will. For Locke to be of help to the pure retributivist, he would have to have identified some kind of ill desert that did not consist in a violation of the Law of Nature, but that nevertheless ought to incur punishment simply because it was wrong, irrespective of any consequences. ${ }^{31}$

Fichte and Locke permit the killing or affliction of the offender because of the comprehensive loss of his rights, as he becomes an "outlaw" (Fichte) or "noxious brute" (Locke). These arguments are difficult to refute, but do not sit easily with our contemporary criminal justice discourse. On a more moderate view than Locke's or Fichte's, not all rights are forfeited by the offender, only whatever rights correspond to the rights violated by the crime. But it is notoriously difficult to make sense of this view, since crimes such as fraud, rape and child abuse do not lend themselves to a denial of corresponding rights as punishment. Moreover, an offender who has gravely afflicted his victim, by violating a right that to the victim is of great importance, may be wholly unaffected by its withdrawal. (For example, an atheist may have committed some crime, such as destroying a holy book or relic, which violates the victim's right 
to unimpeded practice of his religion.) Once we accept that punishment can only in some rather vague way "correspond" to the harm suffered by the victim, the claim about forfeited rights ceases to do any independent work. A right is nothing if what it (or its revocation) implies cannot be more or less exactly stated; and if the revocation of the identical, or some closely-corresponding, right to the one violated leads to absurd consequences, recourse to a vaguer notion of forfeited equivalent rights provides us with no targeted justification for any specific retributive act. We are returned to the bare claim (though expressed in rights-language) that we may afflict people when they have afflicted other people.

Locke, as we have seen, faces up to this implication by, in effect, dividing human beings into (a) the rational majority, who are the contracting parties, and whose contract involves surrendering to society their individual right to punish wrongdoers, and (b) the wrongdoers themselves, who, having quitted reason, are ineligible to participate in the social contract and may be dealt with as beasts. The severity of this vision is underpinned in Locke by an appeal to Divine Law. But if we doubt this appeal (either because we are atheists, or because we are believers who prefer to leave any final condemnation to God), we are simply returned to the rudimentary intuition with which the argument began.

V.

Another, and to my mind the most persuasive, attempt to capture the appeal of the forfeited right notion may be expressed as follows: 
For human beings to live together in peace, certain norms of mutual consideration and forbearance need to be observed. If $\mathrm{X}$ fails to observe these norms in respect of $\mathrm{Y}$, he cannot consistently complain if others fail to observe them in respect of himself. To complain is to appeal to some generally recognized rule. X's complaint would only be successful if there were a generally recognized rule allowing $X$ to perform afflicting acts which others are not allowed to perform. Such a rule might apply if $\mathrm{X}$ were fulfilling some official duty such as that of a police officer, or might arise in a society in which, for example, $\mathrm{X}$ was an arbitrary ruler or a member of some exceptionally privileged elite. But since $\mathrm{X}$ does not act in fulfillment of an official duty, and since we can assume, for the purposes of this discussion, a society that treats all individual wills with equal respect and subjects them equally to the constraints of law, there is no such rule, and therefore, $\mathrm{X}$ has no grounds for complaint if he is afflicted as he has afflicted others.

In short, and assuming a society that treats human beings with equal respect, $\mathrm{X}$ having afflicted another for no good reason has no grounds for complaint if someone similarly afflicts him. It may then be meaningfully be said that he has forfeited his right (his moral right, but it could easily be expressed also as a legal right) to complain..$^{32}$ It is in this sense that one who intentionally threatens another's life or bodily integrity can be said to have forfeited the right to redress if he is killed or injured by the other's acts of self-defense. This person would be like an aggressor in war, who could not reasonably invoke the forbearances required by a condition of peace. $^{33}$ 
By moving from the idea of a forfeited moral right to protection from affliction to that of a forfeited moral right to complain about affliction, we can momentarily take the sting out of one of David Boonin's criticisms of forfeiturebased retributivism. Boonin restates the common objection that "the forfeiture claim . .. entails that a rapist forfeits the right not to be raped and a torturer forfeits the right not to be tortured." ${ }^{34}$ But while this implication is indeed grossly counter-intuitive, it may be less difficult to believe that the rapist and torturer have lost their (moral) rights to complain if they were to be similarly violated. Here, since complaint is an exercise of intellect in argument, it is a matter of rational consistency: the complaining afflictor is caught in a contradiction. This, I suspect, accounts at least partly for the self-evidence of the forfeited right theory to many people: they imagine themselves in an indignant debate with the offender, and see that he, in light of his offense, has no available consistent argument against like-for-like retaliation.

But with this amendment, the supposedly illuminating identity or equivalence between the offender's act and the negated right, as now redefined, disappears entirely. We do not punish a violent criminal for being caught in contradictions, but for committing acts of violence; we impose, not a prohibition on complaining, but some more serious punishment. This punishment (a prison sentence, say) bears no intelligible relation to the loss of the offender's moral right to complain should he himself be violently attacked. And even if, in a Fichtean spirit, we were to construe the loss of the right to complain as applying to all forms of affliction by others, this would still provide no justification for punishment. All that the loss of his right of complaint would entail is that he, the offender, could not consistently appeal to the principle that we should not afflict others without some more than compensating 
good purpose. Anyone else could appeal to that principle in considering how the offender should be treated.

From the proposition that

(4a) X no longer has any grounds (or right) of complaint at being afflicted in a similar way to, or to a similar extent as, his own affliction of Y,

it does not, therefore, follow that it would now be permissible for anyone to afflict him. As W. D. Ross points out, many of our moral obligations towards another, for example to tell the truth, do not seem to be automatically cancelled just because the other party has defaulted on that obligation. ${ }^{35}$ And even if the obligation towards the other has been cancelled, it does not follow that are now permitted to imitate them. It is possible to maintain that we should not afflict people, even if by their voluntary actions they have deprived themselves of any basis for complaining if we do afflict them.

We should consider two further possible arguments in favor of the forfeited right theory. One appeals to the idea of the necessary interdependence of the complete set of rights and the complete set of duties in any system of law. According to this view, when the system is in ideal equilibrium, all rights are respected and all duties are fulfilled. What we call the forfeiting of rights is then a logically necessary feature of the system, since any breach in perfect compliance on the side of duties must have some corresponding effect on the side of rights. Conversely, any removal of a right must also change the total set of duties. 
The weakness of this argument is that it fails to explain why the correspondence between duties and rights should take the form of the forfeiting of a right by the particular individual who has failed to fulfill a duty. The correspondence does not typically take this form in the reverse case, since the removal of my right to a certain benefit $B$ typically has the corresponding effect of cancelling someone else's duty to provide $B$ to me. The merely logical necessity of a corresponding effect within this ideal conception therefore adds nothing to our thinking about the punishment of individuals.

The second argument runs as follows. The domain of Law affirms as its ideal the universality of rights, on which every citizen must be able to rely. If one person's rights are violated, all rights are by implication called into question, unless the universality of rights is reasserted by the act of punishment.

But this argument is open to a simple objection. Why does the act of punishment, if this is conceived as depriving the offender of his right, restore the universality of rights, rather than damaging it further? If it is claimed that in treating the offender's right as forfeit because of his injury to another's right, society expressively affirms the universality of rights, this claim is clearly false, since the offender's right is forfeited and so the universality of rights denied. If it is claimed that treating the offender's right as forfeit repairs the damaged right of the victim and thereby restores the universality of rights, this is even more clearly false, since even if (mysteriously) the punishment somehow "cancelled" the violation of the victim's rights, this cancellation would not restore universality of rights: rather, there would be a time period during which the victim's rights were negated, followed immediately by a time period during which the offender's rights were negated. The evident futility of 
this line of argument helps, I believe, to explain why, with rare exceptions, such as those cited earlier in the paper, courts and jurists have generally preferred not to employ the forfeited right theory when justifying punishment, but have instead worked within a conception in which the criminal law is seen as always affirming and protecting rights, including those of the offender. ${ }^{36}$

VI.

We can return finally to the "defensive" use of the forfeiture theory. According to this view, the idea that the offender forfeits certain rights is not any part of the justification for punishment. Rather, other considerations determine whether or not punishment is justified. But when it is justified, we do certain things to the offender, such as locking him in a cell, that he would generally be thought to have a (moral, not merely legal) right not to have done to him, if punishment were not justified. We need to explain what has happened to this right, and forfeiture provides the best of several possible explanations.

Before turning to those explanations, we should note in passing that there is something odd about this whole "defensive" strategy. It depends on the claim that the task of providing a satisfactory justification of an action can be divorced from the task of explaining why that action does not have a side-effect that should worry us. But this latter task looks suspiciously like a necessary step in justifying the action. If an action is justified but has a worrying side-effect, how can it be entirely justified? A robust consequentialist analysis can quickly answer the question: the action (or the rule permitting this type of action) is justified provided that the resulting benefits 
outweigh the harms caused by the side-effects. It is much harder to answer the question if one is encumbered both with the conviction that the negative moral desert of the offender is a necessary and sufficient permissive justification for punishment, and with the conception of a right as something that is normally inviolable. Given these assumptions, it seems to be splitting hairs to suggest that the forfeiture of moral rights is not to be understood as part of the justification of punishment itself. Let us turn to the possible explanations. There seem to be four.

1. The first explanation concedes that by punishing $\mathrm{X}$, we do infringe (or cancel or suspend $)^{37}$ some right of X's. To punish a person is, by definition, to disadvantage them in some way, and one way of disadvantaging someone is to infringe his rights. Everyone accepts that punishment touches some fundamental concerns of the person and alters the terms of the offender's relation to society. If it did not do so, it would be more like a price-tag, or a tax, or an obligation of public service, which is unwelcome but does not carry punishment's message of reproof and condemnation. That the affliction of the offender cuts into his rights, not merely into his comfort zone, is precisely what marks it as punishment.

We might claim in support of this view that the infringement of a right by way of punishment has an advantage over other interferences, in that a right, when recognized by the law, is part of someone's legal status, and the significance and scope of its infringement can be spelled out. If we are obliged to think about the rights we are infringing, we may be less inclined to punish in an impulsive, uncontrolled, or disproportionate way. There are several problems with this explanation, however. To take the supporting point first, the impression that thinking 
in terms of infringed rights brings order and proportion to punishment is illusory, since actual punishments expressible as the infringement of the identical right (for example, the right to liberty or private property) may vary enormously in severity. Thus, conceptualizing the punishment as the infringement of a right serves to mask, rather than display, the degree of proportionality achieved. We are simply cheering ourselves up by focusing on the generic justification in terms of rights rather than on the more fine-grained and difficult question of the justification of our specific afflicting acts. In the sole significant case where the infringement of a right cannot vary in severity (infringing the right to life), the rhetorical character of the appeal to rights becomes obvious: deciding to destroy X's life and cancelling X's "right to life" are in substance the same thing, though the latter sounds more dignified.

But the deeper problem is that if we view the punishment as infringing $X$ 's rights, rather than merely saying that it involves afflicting $\mathrm{X}$, the special force that distinguishes rights from other considerations of value seems to be unacknowledged. A right, in common understanding, is something that either (i) may never be infringed, or (ii) may not be infringed without some particularly good reason -in this case, a reason that is at any rate stronger than the reason that would be sufficient to justify our choosing the afflicting action if no such right existed. If (i) applies, then we cannot view punishment as infringing rights. If (ii) applies, then we need to know what kind of stronger reason the existence of the right obliges us to find, if we are to justify punishment.

Suppose that we take no account of X's rights, and justify afflicting him on the grounds either that

\section{J1}


by punishing $\mathrm{X}$ for his crime $\mathrm{C}$ with affliction $\mathrm{A}$, we will achieve net benefit

B.

or that

$\mathbf{J} 2$

$\mathrm{X}$ 's crime $\mathrm{C}$ is such that he deserves affliction $\mathrm{A}$.

If we now decide to take account of X's right, and the right is not to be a dead letter, we must have a justification stronger than either $\mathbf{J 1}$ or $\mathbf{J} 2$ to apply A. But there is no obvious way of expressing this revised justification that does not seem speculative and ad hoc: Neither

J1a

by punishing $\mathrm{X}$ for his crime $\mathrm{C}$ with affliction $\mathrm{A}$, we will achieve net benefit $\mathrm{B}+r$

nor

J2a

$\mathrm{X}$ 's crime $\mathrm{C}$ is such that he deserves affliction $\mathrm{A}-r$,

where $r$ represents some quotient corresponding to the modifying effect of the right, seems to capture what we understand by the force of a right. No-one, I believe, conceives of rights in these calibrated terms, nor is there any intelligible basis on which we could decide what value $r$ ought to have. Our real view, if we think along these lines at all, is that $\mathbf{J 1}$ and/or $\mathbf{J} \mathbf{2}$ are sufficient justifications; and that if they involve us in infringing X's right, that is acceptable just because they are sufficient 
justifications. But if that is true, the right has no distinctive force. It is a dead letter, or a mere synonym.

2. The second explanation tries to answer this objection. Here the strategy is to redefine each right so that legal punishment is not, despite appearances, in contradiction to it. On this view, for example, we have a certain right to liberty of the person, the scope of which is limited by those offenses for which custodial sentences are prescribed: hence, if we are punished in such a way for such offenses, our right remains untouched.

This explanation is weak for much the same reason as the first: it fails to acknowledge the distinctive force of the concept of a right. If we redraw the scope of the right in order to accommodate punishment, we are simply saving the appearances at the expense of the integrity of the right; for the explanation to have moral credibility, we would need some independent and non-arbitrary reason for re-defining the right as we do. But it would be extraordinarily good luck if an independentlymotivated definition of the right just happened to have a boundary that corresponded to the limits of legal punishment. What one would hope, instead, would be that the content of the right would logically entail when punishment would be permissible. In the case of liberty of the person, we might start with the idea that

\section{L1}

each person has a right to go wherever she wishes, without let or hindrance, on any business that is lawful. 
$\mathbf{L 1}$ is an attractive candidate for a liberal right: it maximizes freedom of decision and movement while constraining these within the responsibilities of a law-abiding citizen. But $\mathbf{L} \mathbf{1}$ would be violated by imprisonment, since imprisonment prevents us from going where we wish, even on lawful business. So, to avoid its being violated, the right would need to be revised, and we would have to say instead that

\section{L2}

each person has a right to go wherever she wishes, without let or hindrance, on any business that is lawful, unless she has properly been imprisoned for a criminal offense, in which case she cannot even go where she wishes on business that would (otherwise) be lawful.

As soon as we make this unavoidable adjustment, it is apparent that the afflictions involved in punishment are in part determining the content of the right, rather than the content of the right determining the boundaries of permissible punishment. Similar considerations apply to other punishments, such as fines or compulsory community service: if they do not infringe a right, it is only because a potentially plausible right has been deformed to accommodate them. That is the nature of punishment: it attaches an "unless" clause to any plausible corresponding right.

3. The third explanation is the one we have been criticizing, the claim that the right is forfeited. Remember that we are now considering this claim as part of a "defensive" strategy: the punishment of $\mathrm{X}$ is taken to be justified for some other set of reasons, but as a kind of side-issue we have to decide what to say about the right(s) it might 
appear to violate. We cannot therefore appeal to the "aggressive" construal of the theory, which claims that $\mathrm{X}$ in virtue of his offense has actively cast aside the protection of his right, and that his having done so constitutes (at least part of) the justification for punishing him.

But without this construal, what can be meant by saying that he has forfeited his right? Explanation 1 claims that $\mathrm{X}$ possesses a right that is infringed by punishment. Explanation 2 claims that $\mathrm{X}$ possesses a right that is not infringed by punishment. The forfeited right theory attempts to provide a third explanation, by replacing "infringement" with "forfeiture." The verb "to forfeit" contains a certain syntactical and semantic ambiguity, ${ }^{38}$ but a natural interpretation of this replacement is that it transfers responsibility from the punisher to the punished. Someone must bring about the forfeiture: rights do not forfeit themselves. But if the forfeiture is brought about by the offender in the act of committing the crime, then we return to the "aggressive" construal of the forfeited right theory. And if it is brought about by us when we apply the law, then it is merely a rhetorical re-description of infringement, as the term is deployed by Judge Edward Nicholas in the sentencing of Blaine Ross: to say that the offender "has forfeited a right" against punishment $\mathrm{P}$ is just a way of saying, by exploiting the semantic ambiguity of the verb, that the law permits or mandates punishment $\mathrm{P}$ for his offense.

4. The fourth possible explanation of what has happened to the (moral) right of the punished person is that there was no such right in the first place. Only positive, in the sense of legal, rights exist. 
This is, I believe, the correct explanation. We have no moral right not to be afflicted, unless this is just a roundabout way of saying that afflicting people (for no good and sufficient purpose) is wrong and may, if the affliction is serious enough, give reason for the law or public opinion to intervene. The language of moral rights, though it plays a generally unexceptionable rhetorical role in our political discourse (in shining an empowering light on vulnerable or disadvantaged individuals and groups), is a source of confusion in the context of punishment, as the present paper has tried to demonstrate. It is better if we say that, as a matter of individual morality, we ought to help others, and not afflict them without good reason; and that as a matter of collective morality, a good society is one in which the afflicting of people by the authorities is done only for strong compensating reasons, while those individuals who seriously afflict others without some exceptionally good reason (such as self-defense) are deterred, discouraged and if necessary prevented from doing so by effective sanctions.

Admittedly, this is a bit of an ex cathedra dismissal of the moral right model. Other foundations might be offered for the notion that we have a moral right not to be afflicted, which can nevertheless be forfeited. For example, we might, following T. M. Scanlon, say that people have rights that we act towards them in accordance with principles that we could justify to them as reasonable fellow citizens, or fellow human beings. ${ }^{39}$ In that case, they might be said to forfeit some right if they act in a way that brings the relevant situation into the scope of justifiable principle P1 (a principle that permits us to afflict them) rather than justifiable principle P2 (which does not). Or we might, following Stephen Darwall, say that people have rights when they have a "second-personal authority" to demand our compliance with certain ways of acting or 
refraining from acting towards them. ${ }^{40}$ In that case, they might be said to forfeit some right if for some sound reason they no longer have the second-personal authority to demand that we do not afflict them in certain ways. And perhaps the distinctive feature of principle P1 is that it allows the affliction of those who have afflicted others; or the sound reason R for Darwall's hypothetical people to lose secondpersonal authority against our afflicting them is that they have failed to respect the corresponding second-personal authority of others. But for all the distinctiveness of Scanlon's and Darwall's moral theories, it is difficult to see how, in arguing particularly for the justifiability to others of principle S1, or particularly for the soundness of reason $\mathrm{R}$ for second-personal authority to lapse, we could avoid invoking many of the same arguments that have we have already discussed.

I cannot help thinking that the popularity of the idea that the offender should forfeit a right if he has violated that of another owes something to the metaphorical language of possession or ownership in which it is expressed, a language that comes naturally in a culture of which individual property-ownership is a cardinal feature. For if we speak of people possessing (or even simply having) moral rights, it is natural to imagine the possibility that they might lose them, and tempting to wonder whether there are any circumstances in which it would be proper to take them away. If, in contrast, we phrase the question of punishment as I have done elsewhere in this paper, and ask why we should afflict someone purely by reason of his having afflicted another, given a presupposition that afflicting others is wrong, then this temptation is absent: it is now clear that we will need a reason to overturn the usual moral constraint on our actions and that we cannot rely on the claim that the offender, in 
virtue of his criminal action, has laid aside his protective right and hence absolved us of any need to have a more than compensating good purpose.

\section{BIBLIOGRAPHY}

Alm, David. "Self-Defense, Punishment and Forfeiture." Criminal Justice Ethics, 32, no. 3 (2013): 91-107.

Beccaria, Cesare. On Crimes and Punishment. Edited by Richard Bellamy, translated by Richard Davies. Cambridge: Cambridge University Press, 1995.

Blackstone, William. Commentaries on the Laws of England: A Facsimile of the First Edition of 1765--1769. Chicago: University of Chicago Press, 1979.

Boonin, David. Punishment. New York: Cambridge University Press, 2008.

Darwall, Stephen. The Second Person Standpoint: Morality, Respect and Accountability. Cambridge, MA.: Harvard University Press, 2006.

Ferzan, Kimberly Kessler. "Culpable Aggression; the Basis for Moral Liability to Defensive Killing.” Ohio State Journal of Criminal Law 9, no. 2 (2012): 669-98.

Ferzan, Kimberly Kessler. "Inchoate Crimes at the Prevention/Punishment Divide." San Diego Law Review 48, no. 4 (2011): 1273-98.

Fichte, Johann Gottlieb. The Foundations of Natural Right. Translated by Michael Baur. Cambridge: Cambridge University Press, 2000.

Flanagan, James F. "Confrontation, Equity, and the Misnamed Exception for 'Forfeiture' by Wrongdoing." William \& Mary Bill of Rights Journal 14, no. 4 (2006): 1193-1250.

Goldman, A.H. "Towards a New Theory of Punishment." Law and Philosophy 1, no. 1 (1982): 57-76.

Hobbes, Thomas. Leviathan. Edited by R. Tuck. Cambridge: Cambridge University Press, 1996. 
Locke, John. Two Treatises on Government. Edited by Peter Laslett. Cambridge: Cambridge University Press, 1988.

Moore, Michael S. Placing Blame. Oxford: Clarendon Press, 1997.

Morris, Christopher W. "Punishment and Loss of Moral Standing." Canadian Journal of Philosophy 21, no. 1 (1991): 53-77.

Overton, Ben F. "Trial Judges and Political Elections: a Time for Re-Examination." University of Florida Journal of Law and Public Policy 2, no. 1 (1988-89): 9-24.

Quinn, Warren. "The Right to Threaten and the Right to Punish." Philosophy and Public Affairs 14, no. 1 (1985): 327-53.

Ross, W.D. The Right and the Good. Oxford: Clarendon Press, 1930.

Scanlon, T. M. What We Owe to Each Other. Cambridge, Mass.: Harvard University Press, 1998.

Searle, John R. "Human Rights." Chap. 8 in Making the Social World: the Structure of Human Civilization. Oxford: Oxford University Press, 2010.

Simmons, A. John. The Lockean Theory of Rights. Princeton: Princeton University Press, 1992.

Thomson, Judith Jarvis. "Self-Defense.” Philosophy and Public Affairs 20, no. 4 (1991): 283-310.

Wellman, Christopher H. "The Rights Forfeiture Theory of Punishment.” Ethics 122, no. 2 (2012): 371-93.

Wood, A. W. "Fichte's Philosophy of Right and Ethics." In The Cambridge Companion to Fichte, edited by Günter Zöller. New York: Cambridge University Press, Forthcoming. Retrieved from web.stanford.edu/ allenw/papers/Fichte's.doc, September 8, 2015.

\section{NOTES}


[I am grateful to Jonathan Jacobs, Terry Hopton, Alexander Schlutz and a number of anonymous referees for invaluable criticism, advice and encouragement.]

1. I use the slightly archaic term "affliction" for brevity and breadth of reference. It captures the phenomenology -unpleasant or unwelcome experience of some kind-that is common to the crime victim and the punished offender, and it distinguishes this raw experience from the institutional concept of punishment.

2. Some examples are: a surgeon causing temporary pain in order to cure a patient; a driving-test examiner failing a bad driver in order to protect the public; a police officer shooting a terrorist in the act of detonating a bomb.

3. Here are some examples: "Determined to finally win the death penalty fight, Gov. Paul Cellucci filed his administration's toughest capital punishment bill yet and vowed to battle for its passage until the final vote. 'Monsters who take the lives of others have forfeited their own right to live,' Cellucci said. 'They do not deserve hope, they deserve the death penalty.' "StateNet Capital Journal, February 24, 1999; "A Church of England bishop defended the use of the death penalty today. The Bishop of Lichfield said that Saddam's hanging 'cannot be called unjust' and claimed murderers forfeited their own right to life. The Rt. Rev Jonathan Gledhill said: 'Anyone who deliberately murders another human being immediately forfeits his or her own right to life. If Saddam Hussein had a fair trial and proper opportunity to appeal, his execution cannot be called unjust." "The Evening Standard, January 2, 2007, B7.

4. See Quinn, "The Right to Threaten"; Morris, "Punishment and Loss of Moral Standing"; Wellman, "The Rights Forfeiture Theory"; Alm, "Self-Defense, Punishment and Forfeiture." An impressive exception to this approach is Boonin, Punishment.

5. See Alm, “Self-Defense, Punishment and Forfeiture," 92.

6. Quinn, “The Right to Threaten,” 330.

7. See Moore, Placing Blame, 87: "the good that punishment achieves is that someone who deserves it gets it."

8. I do not, of course, mean to imply that the validity of retributivism, even in its purest form, is dependent upon the acceptance of the forfeited right theory. Other arguments in favor of retributivism include the following: there is an intrinsic good in retributive justice, to be distinguished from instrumental goods such as increased utility; punishment is the necessary, or at least permissible, completion of the offender's desert; our emotions when we reflect on crimes reveal to us the moral reality that punishment is called for. These various justifications of retributivism (and there are no doubt others) are interconnected, and to some extent mutually supporting, but for clarity of exposition, analysis, and criticism they are best dealt with one at a time. This paper deals with just one of them.

9. Few retributivists follow Kant in affirming this stringent position, and almost all will accept that there are circumstances in which any prima facie obligation to punish can be overridden. Even such a hard-liner as Moore, for example, remarks that "it is always relevant to ask 'at what cost do we attain some form of justice?"” Moore, Placing Blame, 151.

10. It is possible, indeed, to allude to forfeiture in this non-normative sense even when expressly rejecting the normative arguments for the penalty. Cf. the remarks of the trial judge in State v. Milo A. Rose (1983), cited in Overton, "Trial Judges and Political Elections," 16: "[I]t was my candid belief that ... no one forfeits his right to live until God deems it so. . . But I took an oath when I became a judge and swore that I would uphold the law and the law of this state says that you have forfeited your right to live."

11. See Ferzan, "Inchoate Crimes," 1294-5. 
12. Wellman, "The Rights Forfeiture Theory," 376.

13. Ibid., 377.

14. Ibid.

15. Blackstone, Commentaries on the Laws of England, 4: 375. Italics at "belonged . . community" added; italic at "social" in the original.

16. Goldman, "New Theory of Punishment," 67-8.

17. Morris, "Punishment and Loss of Moral Standing," 61-2, 66.

18. See Hobbes, Leviathan, I, xiv, 91-4.

19. Compare the position of W. D. Ross, who writes of "the leniency with which we should judge deceit, in a case in which no implicit understanding to tell the truth has been established, e.g. ... when one of two savages belonging to different tribes deceives the other. Deceit is much more venial in such a case, because the offender has no reason to suppose that the other is not deceiving, or going to deceive, him." Ross, The Right and the Good, 55.

20. See Beccaria, On Crimes and Punishment, 66.

21. Fichte, The Foundations of Natural Right, 226. It is fair to add that Fichte requires subscription to the civil contract to be actual, not tacit, and unanimous. A person who is unwilling to subscribe is free to form associations elsewhere. See Wood (forthcoming) for a helpful exposition.

22. Locke, Two Treatises on Government, II, s. 172, 382-3.

23. Ibid., s. 135, 358.

24. Ibid., s. 181, 389; cf. s. 16, 279

25. Cf. Searle, "Human Rights,” 174-98.

26. Locke, Two Treatises on Government, II, s. 7, 271.

27. Ibid., s.23, 284.

28. Ibid., s. 24, 284.

29. This, Locke ingeniously argues, is the only way in which we can be thought to consent to slavery: not by a contract, but as the lesser evil in a state of war, which we can always choose to exchange for death by resisting the conqueror's will.

30. See Simmons, The Lockean Theory of Rights, 14-67, especially 26-36, for a discussion of Locke's attempts to reconcile these ideas within a coherent theoretical structure.

31. Having unholy thoughts might have been an example.

32. As Morris puts it, those who "place themselves outside the constraints of justice ... have no grounds of justice to complain." Morris, "Punishment and Loss of Moral Standing," 73. In a related discussion of self-defense, Kimberly Kessler Ferzan writes of culpable aggressors as "forfeiting [their] moral complaint." Ferzan, "Culpable Aggressors," 672.

33. This forfeiting of a right to appeal to a rule that one has oneself broken is quite different from the conception developed by Judith Jarvis Thomson in "Self-Defense." Thomson argues that under certain 
conditions we may kill someone who threatens our life even unintentionally and unknowingly (for example, a fat man falling off a cliff towards us), because he is in the process of violating our right to life and thereby forfeits his right not to be killed by us; while we may not, even to save ourselves, kill an uninvolved bystander, because $h e$ is not violating our right. (Thomson concedes that it may be happier to say that the fat man "lacks," rather than forfeits, the right that you not kill him [301].) I think the common intuitions over Thomson's agent and bystander cases are better explained by saying that we are always prima facie justified in saving our own lives, but -to the extent that this is possible in an emergency- ought to consider whether to kill another would be to do a wrong to which we should prefer our own death, as in Thomson's example of eating a plump baby in order to avoid starvation oneself. How great a wrong a killing would be would depend on many criteria (or such criteria as we were able to deploy, given our limited knowledge and time for reflection), but whether the person threatening us was intentionally doing so would be one of them, for the reason explained in the text.

\section{Boonin, Punishment, 110.}

\section{See Ross, The Right and the Good, 55.}

36. There may seem to be exceptions. The language of forfeiture has sometimes been used when the meaning intended is that a person has knowingly, and in most cases irrevocably, waived the exercise of a right; as when, by pleading guilty, one waives the right to go to trial. Such waivers can take on a normative significance where the intentional action that cancels exercise of the right is itself culpable. The doctrine of "waiver [or forfeiture] by wrongdoing" holds that a defendant cannot, for example, invoke his right to cross-examine a witness, in order to invalidate the use of that witness's pre-trial testimony, if he has himself intentionally prevented the witness's appearance in court. We can accept that any right of a participant that is affirmed within a legal procedure in order best to achieve the objectives of that procedure is waived or forfeited if the participant himself intentionally prevents its fulfillment: the procedure can then, where this is feasible, properly move to the next-best lawful alternative to achieve its objectives without the rights of the disruptive participant having been violated. The defendant cannot, that is, consistently appeal to a right that his own actions have rendered inoperable, and it is for this reason - not as a punishment for wrongful actions towards the witness, which, if criminal, need to be dealt with separately- that the right has no application in this case. Because in ordinary English "forfeiting" has a flavor of reproof that "waiving" lacks, there is a temptation to prefer the former. Moreover, "waiving" can seem counter-intuitive, in that waiving implies willing acceptance of known consequences whether immediate or mediate, whereas the witness-tampering defendant does not in fact will the admission of pre-trial testimony. But if "forfeit" is preferred, its normative flavor should not lead us to think that the non-application of the right is a penalty for wrongdoing. See Flanagan, "Confrontation, Equity, and the Misnamed Exception for 'Forfeiture,' " to which this footnote is largely indebted, for a narrative and critical analysis of the development of the doctrine in U.S. jurisdictions.

37. I use "infringe" as a neutral term for any legally proper cancellation, suspension, attenuation or limitation of a person's right or rights.

38. One can even imagine what linguists call a "mediopassive" use: "some people's rights forfeit easily." But as noted in the running text, this ambiguity must resolve itself into some action of a human being.

39. See Scanlon, What We Owe to Each Other, 189-247 and passim.

40. Darwall, The Second Person Standpoint, 18-20. 